Vol.3 No.1 Hal. 139-144

Juni 2020
ISSN (Print) : $2614-8064$

ISSN (Online): 2654 - 4652

\title{
Efektifitas Model Pembelajaran Kooperatif Tipe Jigsaw Terhadap Peningkatan Hasil Belajar Siswa Pada Materi Pokok Sistem Ekskresi Kelas XI SMA Taman Siswa Tapian Dolok Tahun Pelajaran 2017/2018
}

\author{
Sumarny Tridepina Purba ${ }^{(1)}$, Thiur Dianti Siboro ${ }^{(2)}$, \\ Dosen Program Studi Pendidikan Biologi Universitas Simalungun \\ Sumarny84.purba@gmail.com ${ }^{(1)}$, iyun.siboro@yahoo.co.id ${ }^{(2)}$
}

\begin{abstract}
ABSTRAK
Abstrak

Penelitian ini bertujuan untuk mengetahui Efektifitas Model Pembelajaran Kooperatif Tipe Jigsaw Terhadap Peningkatan Hasil Belajar Siswa Pada Materi Pokok Sistem Ekskresi Kelas XI SMA Tamansiswa Tapian Dolok Tahun Pelajaran 2017/2018. Populasi dalam penelitian adalah seluruh siswa kelas Kelas XI SMA Tamansiswa Tapian Dolok Tahun Pelajaran 2017/2018 yang terdiri dari 4 kelas dengan jumlah siswa 144 orang. Sampel diambil secara acak (Cluster Random Sampling), yaitu kelas kontrol dan kelas eksperimen yang masing-masing terdiri dari 36 siswa. Analisis data dilakukan dengan menentukan skor rata-rata $(\bar{X})$, standart deviasi (S), dan hipotesis dibuktikan dengan menggunakan uji t pada taraf signifikansi $\alpha=0,05$. Dari hasil analisis data maka diperoleh hasil penelitian yaitu t-hitung $(5,51)>t$-tabel $(2,00)$, maka Ho ditolak dan Ha diterima artinya model pembelajaran kooperatif tipe jigsaw efektif terhadap peningkatan hasil belajar siswa pada materi pokok sistem ekskresi kelas XI SMA Tamansiswa Tapian Dolok Tahun Pelajaran 2017/2018. Dari hasil penelitian disimpulkan bahwa model pembelajaran kooperatif tipe jigsaw efektif terhadap peningkatan hasil belajar siswa pada materi pokok sistem ekskresi kelas XI SMA Tamansiswa Tapian Dolok Tahun Pelajaran 2017/2018.
\end{abstract}

Kata Kunci : : Efektifits, Metode Jigsaw, Hasil Belajar

\begin{abstract}
This study aims to determine the Effectiveness of the Jigsaw Cooperative Learning Model on Improving Student Learning Outcomes on the Main Material of Class XI Excretion System Tamansiswa Tapian Dolok High School Academic Year 2017/2018. The population in this study were all students of Class XI SMA Tamansiswa Tapian Dolok in the Academic Year of 2017/2018 consisting of 4 classes with 144 students. The sample was taken randomly (Cluster Random Sampling), which is the control class and the experimental class, each consisting of 36 students. Data analysis was performed by determining the average score $((\mathrm{X}) \overline{)}$, standard deviation (S), and the hypothesis was proven by using the $t$ test at the significance level $\alpha=0.05$. From the results of data analysis, the research results obtained are t-count (5.51) $>\mathrm{t}$-table (2.00), then Ho is rejected and $\mathrm{Ha}$ is accepted, meaning that the Jigsaw type cooperative learning model is effective in increasing student learning outcomes in the subject matter of the excretion system. class XI Tamansiswa Tapian Dolok High School 2017/2018 Academic Year. From the results of the study it was concluded that the Jigsaw type cooperative learning model was effective in increasing student learning outcomes on the subject matter of the XI class excretory system Tamansiswa Tapian Dolok High School Academic Year 2017/2018.
\end{abstract}

Keywords : Effective, Jigsaw Method, Learning Outcomes 
Purba Sumarny T, Siboro Thiur D : Efektifitas Model Pembelajaran Kooperatif Tipe Jigsaw Terhadap Peningkatan Hasil Belajar Siswa Pada Materi Pokok Sistem Ekskresi Kelas XI SMA Taman Siswa Tapian Dolok Tahun Pelajaran 2017/2018

\section{PENDAHULUAN}

\section{Latar Belakang}

Kekurangan terlibatan siswa dalam kegiatan pembelajaran di kelas akan menghambat atau menghalangi siswa dalam memahami pelajaran tersebut yang akan berakibat prestasi belajar siswa yang cenderung rendah (Margono 2010). Oleh karena itu, perlu melakukan penelitian mengenai metode pembelajaran yang kreatif produktif, yang menuntut siswa untuk lebih kreatif dalam pemecahan masalah, dan mampu menciptakan sesuatu hal dari pemikiran mereka sendiri. Pendekatan konvensional ditandai dengan guru mengajar lebih banyak mengajarkan tentang konsep-konsep bukan kompetensi, pada saat proses pembelajaran siswa lebih banyak mendengarkan. Pendekatan konvensional adalah proses pembelajaran yang lebih banyak didominasi gurunya sebagai pentransfer ilmu sementara siswa lebih pasif sebagai penerima ilmu. Menurut Budiningsih (2005), pembelajaran kreatif dan produktif adalah model yang dikembangkan dengan mengacu kepada berbagai pendekatan pembelajaran yang diasumsikan mampu meningkatkan kualitas proses dan hasil belajar.

\section{Rumusan Masalah}

Pada pembelajaran dengan cara ceramah, biasanya siswa diposisikan sebagai objek, yang dianggap tidak tahu atau belum tahu apa-apa (Djamarah 2006). Pembelajaran biologi pada materi Sistem Eksresi yang berlangsung selama ini masih pembelajaran yang berpusat pada guru.

\section{Tujuan Penelitian}

Adapun tujuan penelitian ini dilakukan untuk mengetahui efektifitas model pembelajaran kooperatif tipe jigsaw terhadap hasil belajar siswa pada materi pokok sistem ekskresi kelas XI SMA Tamansiswa Tapian Dolok Tahun Pelajaran 2017/2018.

\section{Manfaat Penelitian}

Adapun manfaat penelitian ini adalah:

a. Siswa dapat menerima pembelajaran dengan strategi belajar yang berbeda, sehingga mereka tidak jenuh dan tertarik untuk mengikuti pembelajaran.

b. Sebagai bahan masukan bagi guru untuk lebih memperhatikan penggunaan metode pembelajaran.

c. Bagi guru biologi/ pihak penyelenggara pendidikan dapat dijadikan salah satu alternatif metode pengajaran yang diharapkan dapat mengatasi sikap monoton dalam mengajar dan meningkatkan hasil belajar biologi siswa

\section{METODE PENELITIAN}

\section{Lokasi dan Waktu Penelitian}

Penelitian ini dilakukan di kelas XI SMA Tamansiswa Tapian Dolok.

\section{Populasi dan Sampel}

1) Populasi

Ridwan (2009:55) mengatakan "Populasi adalah objek atau subjek yang berada pada suatu wilayah dan memenuhi syarat-syarat tertentu yang berkaitan dengan masalah penelitian." Berdasarkan pendapat tersebut, maka penulis menetapkan populasi penelitian ini adalah seluruh siswa kelas XI SMA Tamansiswa T.P. 2017/2018 yang terdiri dari 4 kelas dengan jumlah 144 orang.

2) Sampel

Sampel adalah sebagian dari populasi yang akan diteliti. Pengambilan sampel dilakukan secara cluster random sampling, langkah-langkah pengambilan sampel sebagai berikut: 
Purba Sumarny T, Siboro Thiur D : Efektifitas Model Pembelajaran Kooperatif Tipe Jigsaw Terhadap Peningkatan Hasil Belajar Siswa Pada Materi Pokok Sistem Ekskresi Kelas XI SMA Taman Siswa Tapian Dolok Tahun Pelajaran 2017/2018

a. Mengurutkan kelas siswa yang menjadi populasi

b. Membuat gulungan kertas sebanyak kelas populasi

c. Memasukkan kertas ke dalam botol

d. Mencabut gulungan kertas yang ada di botol

e. Gulungan yang telah tercabut ditetapkan sebagai sampel

Setelah diacak maka yang menjadi sampel adalah kelas $\mathrm{X}^{1}$ dan $\mathrm{X}^{2}$.

\section{Desain Penelitian}

Sampel yang diambil dalam penelitian ini dikelompokkan atas dua kelas, yaitu kelas $\mathrm{X}$ 2(kelas eksperimen) dan kelas X-3 (kelas kontrol) sebanyak 36 setiap kelas.

Desain Penelitian

\begin{tabular}{|l|l|l|l|}
\hline Kelompok & Tes Awal & Perlakuan & Tes Akhir \\
\hline Kelas X-2 (eksperimen) & $\mathrm{T}_{1}$ & $\mathrm{X} 1$ & $\mathrm{~T}_{2}$ \\
\hline Kelas X-3 (kontrol) & $\mathrm{T}_{1}$ & $\mathrm{X} 2$ & $\mathrm{~T}_{2}$ \\
\hline
\end{tabular}

Keterangan :

$\mathrm{T}_{1}=$ Pretes

$\mathrm{T}_{2}=$ Postes

$\mathrm{X} 1=$ Pengajaran menggunakan model pembelajaran Jigsaw

$\mathrm{X} 2$ = Pengajaran menggunakan model pembelajaran konvensional

\section{Instrumen Penelitian}

Instrumen yang digunakan dalam penelitian ini berupa tes tertulis. Tes adalah rentetan pertanyaan yang digunakan untuk mengukur keterampilan, pengetahuan inteligensi, kemampuan atu bakat yang dimiliki oleh individu atau kelompok. (Arikunto, 2004:193). Peneliti membagikan tes berupa pre-test (sebelum proses belajar mengajar dimulai) dan posttest (setelah materi selesai diajarkan) berupa pilihan ganda dengan pilihan A, B, C, D, dan E sebanyak 10 pertanyaan, dengan nilai 1 tiap jawaban benar.

\section{Prosedur Pengumpulan Data}

Prosedur penelitian terdiri atas tiga tahap yaitu:

1) Tahap persiapan pengajaran

a. Menyusun jadwal penelitian.

b. Membuat Rencana Pelaksanaan Pembelajaran (RPP) dimana dalam RPP ini metode mengajar yang digunakan adalah model Jigsaw dan metode konvensional.

c. Menyiapkan bahan ajar (materi pokok).

2) Tahap pelaksanaan di kelas

a. Memberikan pre-test pada siswa di kelas eksperimen dan kelas kontrol.

b. Mengajarkan materi sistem eksresi pada kelas eksperimen

c. Mengajarkan materi sistem eksresi di kelas kontrol.

3) Tahap Penyelesaian Penelitian

a. Menganalisis hasil nilai pre-test dan post-test siswa kelas eksperimen diajarkan dengan model pembelajaran jigsaw dan kelas kontrol yang diajarkan dengan metode konvensional.

b. Membandingkan hasil eksperimen yang menggunakan model pembelajaran jigsaw dan metode konvensional dengan melewati berbagai organisasi pengolahan data.

c. Membuat kesimpulan dan saran dari proses penelitian yang telah dilakukan.

d. Membuat laporan penelitian. 
Purba Sumarny T, Siboro Thiur D : Efektifitas Model Pembelajaran Kooperatif Tipe Jigsaw Terhadap Peningkatan Hasil Belajar Siswa Pada Materi Pokok Sistem Ekskresi Kelas XI SMA Taman Siswa Tapian Dolok Tahun Pelajaran 2017/2018

\section{Teknik Analisis Data}

1. Menghitung rata-rata $(X \overline{)}$ digunakan rumus :

$$
\bar{X}=\frac{\sum X i}{n}
$$

Keterangan :

$$
\begin{array}{ll}
\bar{X} & =\text { nilai rata-rata } \\
\sum X i & =\text { jumlah nilai } \\
\mathrm{n} & =\text { jumlah sampel }
\end{array}
$$

2. Menghitung standar deviasi digunakan rumus :

$$
\begin{aligned}
\mathrm{S}=\frac{1}{n} \sqrt{\left(n \sum X i^{2}\right)-\left(\sum X i\right)^{2}} & =\text { Standart Deviasi } \\
\text { Keterangan }: \mathrm{S} \quad & \text { Jumlah Nilai } \\
\sum X i & =\text { Jumlah Kuadrat nilai } \\
\sum X i^{2} & =\text { Jumlah Sampel }
\end{aligned}
$$

\section{HASIL DAN PEMBAHASAN}

Penelitian ini berjudul "efektifitas model pembelajaran kooperatif tipe jigsaw terhadap peningkatan hasil belajar siswa pada materi pokok sistem ekskresi kelas XI SMA Tamansiswa Tapian Dolok Tahun Pelajaran 2017/2018". Dalam penelitian ini yang menjadi populasi adalah seluruh siswa yang belajar di kelas XI SMA Swasta Tamansiswa Tapian Dolok Tahun Pelajaran 2017/2018 yang terdiri dari 4 kelas dengan jumlah siswa 144 orang dan sampelnya adalah kelas XI-2 sebagai kelas eksperimen dan kelas X-3 sebagai kelas kontrol yang masing-masing terdiri dari 36 siswa. Data yang diperoleh dalam penelitian ini adalah data post test kelas kontrol maupun kelas eksperimen pada materi sistem ekskresi di kelas XI SMA Swasta Tamansiswa Tapian Dolok Tahun Pelajaran 2017/2018.

Tabel Distribusi Frekuensi Data Post Test Kelas Kontrol

\begin{tabular}{|cc|c|c|c|c|}
\hline & & Frequency & Percent & Valid Percent & Cumulative Percent \\
\hline Valid & 3.00 & 4 & 11.1 & 11.1 & 11.1 \\
& 4.00 & 7 & 19.4 & 19.4 & 30.6 \\
& 5.00 & 10 & 27.8 & 27.8 & 58.3 \\
6.00 & 10 & 27.8 & 27.8 & 86.1 \\
& 7.00 & 5 & 13.9 & 13.9 & 100.0 \\
& Total & 36 & 100.0 & 100.0 & \\
\hline
\end{tabular}

Dari diatas dapat di simpulkan, bahwa siswa yang mendapat nilai 3 berjumlah 4 orang $(11,1 \%)$, nilai 4 berjumlah 7 orang $(19,4 \%)$, nilai 5 berjumlah 10 orang $(27,8 \%)$, nilai 6 berjumlah 10 orang $(27,8 \%)$, dan nilai 7 berjumlah 5 orang $(13,9 \%)$. KKM pada mata pelajaran biologi adalah 7, dari 36 orang siswa kelas kontrol, yang mencapai KKM hanya berjumlah 5 orang $(13,9 \%)$. 
Purba Sumarny T, Siboro Thiur D : Efektifitas Model Pembelajaran Kooperatif Tipe Jigsaw Terhadap Peningkatan Hasil Belajar Siswa Pada Materi Pokok Sistem Ekskresi Kelas XI SMA Taman Siswa Tapian Dolok Tahun Pelajaran 2017/2018

Tabel Distribusi Frekuensi Data Post Test Kelas Eksperimen

\begin{tabular}{|cc|c|c|c|c|}
\hline & & Frequency & Percent & Valid Percent & Cumulative Percent \\
\hline Valid & 4.00 & 2 & 5.6 & 5.6 & 5.6 \\
& 5.00 & 6 & 16.7 & 16.7 & 22.2 \\
& 6.00 & 6 & 16.7 & 16.7 & 38.9 \\
& 7.00 & 10 & 27.8 & 27.8 & 66.7 \\
& 8.00 & 8 & 22.2 & 22.2 & 88.9 \\
& 9.00 & 4 & 11.1 & 11.1 & 100.0 \\
& Total & 36 & 100.0 & 100.0 & \\
\hline
\end{tabular}

Dari tabel diatas dapat dilihat bahwa siswa yang mendapat nilai 4 berjumlah 2 orang $(5,5 \%)$, nilai 5 berjumlah 6 orang $(16,7 \%)$, nilai 6 berjumlah 6 orang (16,7\%), nilai 7 berjumlah 10 orang $(27,8 \%)$, nilai 8 berjumlah 8 orang $(22,2 \%)$, dan nilai 9 berjumlah $4(11,1 \%)$. KKM pada mata pelajaran biologi adalah 7 , dari 36 orang siswa kelas eksperimen yang memenuhi KKM berjumlah 22 orang $(66,1 \%)$.

Tabel Uji Hipotesis Data Post Test Kelas kontrol dan Eksperimen

Paired Samples Test

\begin{tabular}{|c|c|c|c|c|c|c|c|c|}
\hline & \multicolumn{5}{|c|}{ Paired Differences } & \multirow[b]{3}{*}{$\mathrm{t}$} & \multirow[b]{3}{*}{$d f$} & \multirow[b]{3}{*}{ Sig. (2-tailedl } \\
\hline & \multirow[b]{2}{*}{ Mean } & \multirow{2}{*}{ Std. Deviation } & \multirow{2}{*}{$\begin{array}{c}\text { Std. Error } \\
\text { Mean }\end{array}$} & \multicolumn{2}{|c|}{$\begin{array}{c}\text { 95\% Confidence } \\
\text { Interval of the } \\
\text { Difference }\end{array}$} & & & \\
\hline & & & & Lower & Upper & & & \\
\hline $\begin{array}{ll}\text { Pair } & \text { Post Test Kontrol } \\
1 & \& \text { Eksperimen }\end{array}$ & $-1,63$ & 1,85 & 0,32 & $-1,09$ & 0,20 & 5,51 & 35 & 0,000 \\
\hline
\end{tabular}

Berdasarkan tabel di atas diperoleh t-hitung $(5,51)>\mathrm{t}$-tabel $(2,00)$, maka Ho ditolak dan Ha diterima artinya model pembelajaran kooperatif tipe jigsaw efektif terhadap peningkatan hasil belajar siswa pada materi pokok sistem ekskresi kelas XI SMA Tamansiswa Tapian Dolok Tahun Pelajaran 2017/2018.

\section{Pembahasan Penelitian}

Dari hasil penelitian diperoleh jumlah nilai post-test kelas kontrol sebesar 185 dengan ratarata 5,13. Sedangkan jumlah nilai post test untuk kelas eksperimen sebesar 244 dengan ratarata 6,77. Jika dibandingkan nilai rata-rata post test kelas kontrol $(5,13)$ dan eksperimen $(6,77)$ diperoleh perbedaan hasil belajar sebesar 1,64. Hal ini membuktikan bahwa pembelajaran pada sistem eksresi dengan menggunakan model pembelajaran kooperatif tipe Jigsaw sangat efektif dalam peningkatan prestasi belajar siswa kelas XI SMA Swasta Tamansiswa Tapian Dolok Tahun Pelajaran 2017/2018. Hal ini dikarenakan kelompokkelompok siswa di kelas pembelajaran kreatif produktif lebih terfokus pada tugasnya masing-masing sehingga siswa lebih aktif untuk menciptakan produk kreatif karena lebih memahami materi yang disampaikan oleh guru. Selanjutnya dari hasil pengujian hipotesis menggunakan uji t diperoleh t-hitung $(5,52)>t$ - tabel $(2,00)$. Dengan demikian Ha diterima dan Ho ditolak artinya model pembelajaran kooperatif tipe jigsaw efektif terhadap peningkatan hasil belajar siswa pada materi pokok sistem ekskresi kelas XI SMA Tamansiswa Tapian Dolok Tahun Pelajaran 2017/2018 
Purba Sumarny T, Siboro Thiur D : Efektifitas Model Pembelajaran Kooperatif Tipe Jigsaw Terhadap Peningkatan Hasil Belajar Siswa Pada Materi Pokok Sistem Ekskresi Kelas XI SMA Taman Siswa Tapian Dolok Tahun Pelajaran 2017/2018

\section{KESIMPULAN}

1) Skor rata-rata hasil belajar siswa kelas eksperimen pada post tes adalah 6,77 .

2) Skor rata-rata hasil belajar siswa kelas kontrol pada post-test 5,13

3) Adanya perbedaan hasil belajar siswa dengan menggunakan model pembelajaran kreatif produktif pada materi ekosistem di kelas X SMA Swasta Tamansiswa Tapian Dolok sebesar 1,64.

4) Dari pengujian hipotesis diperoleh t-hitung $(5,52)>$ t-tabel $(2,00)$. Maka Ha diterima dan Ho ditolak artinya ada perbedaan yang berarti hasil belajar siswa dengan menggunakan model pembelajaran kreatif produktif pada materi masalah lingkungan di kelas X SMA Swasta Tamansiswa Tapian Dolok Tahun Pelajaran 2014/2015.

\section{DAFTAR PUSTAKA}

Arikunto, Suharsimi. 2004 .Prosedur Penelitian. Jakarta: Bumi Aksara

Budiningsih, Asri. 2005. Belajar dan Pembelajaran. Jakarta: PT Rineka Cipta

Departemen Pendidikan Nasional. 2007. Makalah Pembelajaran Kreatif Produktif

Djamarah, 2006. Strategi Belajar Mengajar. Jakarta : Rineka Cipta

Margono, 2010. Metodologi Penelitian Pendidikan. Jakarta : Rineka Cipta

Priojosaksono, Ariwibowo. http://www.inline.or.id

Rianawati, Ida. http://idarianawaty.blogspot.co.id/2011/02/model-pembelajaran-kreatifproduktif.html?m=1

Ridwan, 2009. Metode dan Teknik Penelitian.Bandung : Alfabeta

Rusman, 2010. Model-Model Pembelajaran. Bandung : Rajawali Pers

Sudjana, 2005. Metoda Statistika. Bandung : Tarsito

Susanto, 2006. Metode Penelitian. Surakarta : UNS Press

Wena, Made. 2009. Strategi pembelajaran inovatif kontemporer suatu tinjauan konseptual operasional. Jakarta: Bumi Aksara. 